UDC 37.013

DOI https://doi.org/10.24919/2308-4863/40-1-38

\author{
Afag Gulam GASIMOVA, \\ orcid.org/0000-0002-9136-4840 \\ Doctor of Philosophy in Agrarian Sciences, \\ Lecturer at the Department of Biology \\ of the Faculty of Chemistry and Biology \\ Ganja State University \\ (Ganja, Azerbaijan) afaqqasimova@bk.ru
}

\title{
THE IMPORTANCE OF FOLLOWING THE PRINCIPLES OF EDUCATION IN THE TEACHING OF BIOLOGY
}

The purpose of this article is to explore the possibilities and ways to refer to the principles of teaching in the process of teaching biology.

The article discusses practical examples of addressing the principles of learning in the process of teaching biology and a number of practical approaches.

Methods and methodology. The article uses methods of classification of general pedagogical and general didactic principles that must be taken into account in the learning process. The method of analyzing the principles of teaching necessary for teaching biology was also used. The article also presents both theoretical and practical approaches to existing opportunities and effective ways of addressing the principles of teaching in the process of teaching biology.

Innovation. The article presents new ideas and conceptual scientific ideas about existing opportunities and a number of effective ways to address the principles of teaching in the process of teaching biology. The above can be considered as the scientific novelty of the article.

Research results. Revealed the importance of following the principles of teaching in the process of teaching biology. When organizing visibility in biology lessons, it is considered necessary to comply with all the nuances of pedagogical requirements.

In organizing visibility, it is necessary to work to help students discover their ability to search and explore.

Thus, visibility is one of the most important principles of the educational process, and each link of this principle contributes to the scientific worldview, all-round development and the level of education of students. The organization of the binary learning process inside the rings of the principle of visibility and the expansion of the facts of visual observation contribute to the successful solution of the task. Because binary lessons can be organized not only in the classroom, in the biology class, but also in the teaching and practice of biology, in any green zone, so that students can visually assimilate the system of knowledge, skills and habits.

Despite all this, it is important to note that in the process of teaching biology, the comprehensive development of students can be ensured through the use of opportunities and effective methods of purposeful, systematic, organized appeal to the learning process.

Key words: Biology lessons, teaching process, teaching principles, students' worldview, personality-oriented education.

ГАСИМОВА Афаг Гулам гизи, orcid.org/0000-0002-9136-4840 доктор філософії з аграрних наук, викладач кафедри біології хіміко-біологічного факультету Гянджинського державного університету (Гянджа, Азербайджан) afaqqasimova@bk.ru

\section{ВАЖЛИВІСТЬ СЛІДУВАННЯ ПРИНЦИПАМ ОСВІТИ У ВИКЛАДАННІ БІОЛОГІї}

\footnotetext{
Мета цієї статmі - вивчити можливості і способи використання принципів викладання в процесі навчання біології.

У статті розглядаються практичні приклади звернення до принципів навчання в процесі навчання біології $i$ низка практичних підходів.

Методи і методологія. У статті використані методи класифікації загальнопедагогічних $і$ загальнодидактичних принципів, які необхідно враховувати в процесі навчання. Також використаний метод аналізу принципів навчання, щчо необхідні для викладання біології. Також у статті представлені як теоретичні, так $і$ практичні підходи до наявних можливостей і дієвих способів звернення до принцииів навчання в прочесі навчання біологї̈.

Нововведення. У статті представлені нові ідеї та концептуальні наукові уявлення про наявні можслвості i низку ефективних способів звернення до принципів викладання в процессі викладання біології. Вищевикладене можна розглядати як наукову новизну статті.
} 
Результати дослідження. Виявлена важливість дотримання принципів викладання в процесі викладання біології. Для організачії наочності на уроках біології вважається необхідним дотримання всіх нюансів педагогічних вимог.

У разі організаиії наочності необхідно праџювати, щуоб допомогти студентам розкрити свої здібності до пошуку і дослідження.

Таким чином, наочність - один з найважливіших принцииів навчального процесу, кожна ланка ццього принцииу сприяє науковому світогляду, всебічному розвитку та рівню освіти студентів. Організація бінарного процесу навчання у рамках принципу наочності і розширення фактів візуального спостереження сприяє успішному вирішенню поставленого завдання. Тому що бінарні уроки можуть бути організовані не тільки в класі, в класі біологї, але і у сфері викладання та практики біологї, в будь-якій зеленій зоні, щзоб учні могли візуально засвойти систему знань, навичок $і$ звичок.

Незважаючи на все це, важливо відзначити, щзо в процесі викладання біології всебічний розвиток студентів може бути забезпечений за рахунок використання можливостей і ефективних способів цілеспрямованого, планомірного, організованого звернення до процесу навчання.

Ключові слова: уроки біології, навчальний процес, принципи навчання, світогляд студентів, особистісно зорієнтоване навчання.

Introduction (problem statement). The directives on education reform in Azerbaijan, as well as the State Strategy for the Development of Education in Azerbaijan, set important tasks for subject teachers to create a new content of personality-oriented education. Due to the successful solution of these tasks, the creative use of modern learning technologies, principles, methods and tools of teaching in the process of teaching subjects is of great importance. One of the main tasks of subject teachers is to create a new content of purposeful, planned and organized reference to the principles of teaching in the process of teaching all subjects in secondary schools. As in the process of teaching all subjects, it is important to create a new model of teaching the principles of teaching biology. Therefore, in the process of teaching biology, it is necessary to acquaint students with the secrets of the biological world, referring to the principles of teaching that exist in the world education system.

The purpose of this article is to explore the possibilities and ways to refer to the principles of teaching in the process of teaching biology. Among the goals of the research is the use of the results by teachers of biology, zoology, botany, natural sciences.

Methodology and methods used. The article discusses practical examples of reference to the principles of teaching in the process of teaching biology and a number of practical approaches. The article classifies the general pedagogical and general didactic principles that need to be referred to in the learning process. It also analyzes the teaching principles necessary for the teaching of biology. The article provides both theoretical and practical approaches to the existing opportunities and effective ways to refer to the principles of teaching in the process of teaching biology.

Recent publications on the subject emphasize the creation of a new model of reference to the principles of teaching in the teaching of biology, as in the teaching of all subjects. Therefore, in the process of teaching biology, it is necessary to acquaint students with the secrets of the biological world, referring to the principles of teaching that exist in the world education system.

Researcher F. B. Sadigov in his work analyzes the relationship between the educational process and the principles of learning, notes that if the knowledge taught is not linked to modern life, the development of society, that knowledge becomes a meaningless burden for the student. In this case, students' interest in scientific knowledge decreases, the level of consciousness and activity decreases. Therefore, the teacher must explain to students the vital importance of the material taught, both in the teaching of the subject and in individual subjects. The teacher must connect individual facts and events with the processes taking place in the region, the republic, the world where the students live, and achieve a lively, creative lesson. For this, first of all, the teacher must have his own knowledge, scientific-theoretical training, broad outlook. This structure of the academic year prepares students for practical participation in socio-economic and cultural life (Sadiqov, 2010: 170).

On the importance of the application of new technologies in the teaching of biology, F.M. Orujov's textbook "Directions of application of new technologies in teaching biology" is of great importance. The methodical manual reflects the essence, possibilities and directions of application, interactive methods, results and suggestions of new technologies in teaching biology. On the basis of these facts, school experience is analyzed, interactive materials from biology, chemistry, physics and mathematics are generalized and interactive knowledge is developed. The textbook covers the fields of biology related to chemistry, physics and mathematics. It defines the directions of examples of design and solution of problems related to integrative areas. The manual can be used by teachers, methodologists, entrants and high school students (Orujov, 2007). 
Great Russian pedagogue K. D. Ushinsky preferred to make comparisons during the visual demonstration. The creator of national pedagogy, N. M. Kazimov, considers the demonstration of visibility to serve the formation of relevant concepts in children, and suggests that the principle of visibility is born from this regularity. N. M. Kazimov, who introduced this principle as "the principle of visualization in learning" (demonstration of plants, seeds, seedlings, leaves, trees, rocks, insects, music and fine arts, etc.) in the learning process"; "Image visibility" (display of original images); verbal visualization (creating a vivid image through words); "Conditional visibility" (scheme, map, diagram, drawing); Prefers the use of such types as "moving visuals" (film, television, audio, visual, audio-visual means) (Kazimov, 2006). Thus, in addition to the visual representation of flowers, blossoms, plants, birds, animals, hydrosphere and other living things in the biosphere on the basis of software materials, the most important principle of visibility is the visual display of their images and models by computer technology are considered symptoms.

Konul Kazimli in his scientific article "Features of the application of active learning methods in the teaching of biology" notes that active learning methods do not completely negate traditional teaching methods. Because problem-based learning, developmental training, collective learning methods, which have been widely used in the education system for many years, have not lost their relevance in our time. However, the use of active learning methods is one of the most important challenges facing the modern education system. The author notes that the application of active learning methods develops the student's mental characteristics - emotion, perception, character and enthusiasm and interest in the lesson. The article mentions active learning methods and analyzes them (Kazimli, 2017, 124-125).

Analysis of important principles to be referred to in the process of teaching biology. One of the principles of teaching that is important to refer to in the teaching of biology is the principle of linking teaching with modern life and state directives. This principle is one of the most widely used principles in pedagogy and helps to increase the effectiveness of teaching. Coordinating the training with state directives also acquaints them with the legislation on environmental protection. As it is known, the protection of the biological environment, as well as the ecological world, always attracts attention with its urgency. In order to instill this in students, it is necessary to bring to the attention of students the directives on the protection of the biological environment by the state. For example, the Law of the Republic of Azerbaijan on Environmental Protection
(N608-IQ of June 8, 1998) stipulates that the list of objects of special environmental protection of special scientific-ecological and biological importance must be approved, state reserves, state national and nature parks, other special protection to organize demanding natural areas and objects; Exercising state control over the protection, restoration and use of the environment, fauna and flora is a requirement of the day (Ecological legislation of the Republic of Azerbaijan (collection of normative-legal acts, 2006, 5). Familiarization of students with such legislation increases their interest in the protection of the biological environment. For example, in the process of teaching the topic "Flowering plants" in the 6th grade, by bringing to the attention of students the protection of such plants by the state, there are opportunities to educate students in the spirit of loyalty to the Azerbaijani statehood. From this point of view, there are many advantages of referring to the principle of linking teaching in biology lessons with modern life and state directives.

One of the principles of teaching that needs to be referred to in biology lessons is the educational, nurturing and developmental principle of teaching.

Under this principle, the educational, educative and developmental functions of training are based. Each of them is seen in interaction. As it is known, training is a process of implementation of education, and education is considered both the basis and the result of training. If, during the educational principle, students acquire the knowledge, skills and habits provided for in the program, through the educational function, work is carried out with them on moral, spiritual, aesthetic, labor, environmental, economic education. The developmental principle means the development of students' physical and mental strength. Physical forces include walking, running, swimming, jumping, and so on qualities. Mental forces include emotions, perception, imagination, thinking, attention, and so on belongs to. Each of these can have a certain educational effect on students. Therefore, the teacher must always make effective use of the educational power of teaching, to determine the right direction in this work. In the application of this principle, the teacher-student relationship must demonstrate kindness, humanism, simplicity, care, and show a combination of respect and demand (Sadikov, 2011: 170-171).

A teacher who is creative in his approach to the study of any subject in the teaching of biology must take an educative approach to imparting new knowledge. For example, in Grade VII, when teaching about "covered plants", the teacher develops educational and nurturing feelings in children by referring to additional literature, that is, by informing about the rare types of covered plants when approaching 
the subject creatively. By getting information about strange flowers, students get new information about flowers that enter the orchids and open underground. The teacher points out that some species of orchids growing on the fifth continent bloom underground.

No one still knows how they do it. There are also many questions: for example, they use their own pollen in pollination. But how do they use pollen from other plants? The question is natural, but the answer has not yet been found. The flowers of many trees growing in the thickets grow on their trunks and large branches. This attracts the bats involved in the pollination of the flowers of the creatures that feed on the nectar of these flowers (Tahirli, 2004: 5). The teacher, who provides the impressive information provided, instructs the students to look for such information. That is, they try to reveal their research abilities. The teacher notes that flowers are rare pearls of nature, so it is the conscientious duty of every person to protect, love and care for them. Such an approach leads to the educational and pedagogical development of students. One of the principles that must be applied in the teaching of biology is the scientific principle of teaching.

With the help of this principle, innovations in various fields of science are brought to the content of training. The principle of science is based on a number of scientific provisions. These are (Eliyev, 2020):

1. In order for students to acquire scientific knowledge, it is necessary to ensure a correct, objective perception of the objects and events they have learned.

2. Students must have a deep understanding of the important features and properties of objects, the connections and relationships between objects and events.

3. The science of teaching is also based on the precise application of terms. In science, only accepted terms should be used and old terms should be compared.

4. In order to properly master the studied objects and events, students must understand their modern scientific nature, internal laws. The picture of the development of the studied events must be revived in their imagination. The scientific principle should be taken into account in the teaching sequence of teaching materials. Both in the textbook and in the teacher's commentary, the knowledge imparted to the student must be presented in a consistent, coherent, and understandable way for the students.

In biology lessons, it is important to take into account all aspects of the principle of learning when giving information about intestinal cavities, flatworms, roundworms, mollusks, mustard, scorpions, fish, amphibians, reptiles, and mammals, so that students learn the etymology of terms in these sections they master the shades of meaning. In this case, all conditions are created for the systematic analysis of other topics included in the program. From this point of view, it is important to refer to the principle of systematization and consistency in the teaching of biology. As it is known, the compilation of didactic material and the transfer of knowledge should be systematic. Systematicity should be based on the logic of the content of the topic. The finished parts and sections of the topic are the main elements of this system. Clients point out that the disruption of systematic and consistent training makes it extremely difficult to master knowledge.

Systematic acquisition of knowledge ensures the consistent development of students' cognitive powers and abilities (Sadikov, 2012: 174). This means that in addition to providing knowledge from relevant textbooks prepared in accordance with the program materials, the systematic and consistent knowledge provided on the basis of additional literature, auxiliary teaching aids based on pedagogical innovations increases the level of thinking and cognitive activity of students. For example, in the process of teaching the subject of fish in biology classes, it is necessary to create a whole didactic system of information about fish in the program materials with information taken from auxiliary materials. The teacher shows that, dear students, the topic of fish in your textbook introduces you to the system of fish in the biological environment. Along with all this, it should be noted that there are about 200 species of fish in the rivers, lakes and the Caspian Sea of Azerbaijan. Among these species, such as sturgeon, crooked and needle fish are considered to be non-fish in the world's hydrosphere system. When sturgeons reach the age of 16-17, they begin to reproduce. In the process of reproduction, they release millions of caviar into the hydrosphere. Sturgeons, which live to 70-80, sometimes 90-100 years of age, are popularly considered white fish.

In the scientific literature, it is called regional fish (beluga, sturgeons, stellate sturgeon). Such information not only increases students' thinking and cognitive activity, but also raises their scientific outlook and intellectual level. One of the principles referred to in biology classes is called the principle of consciousness, activity and independence through learning.

Consciously acquired active learning work must be perceived and strengthened independently. Because of the acquisition of knowledge by students takes place in the process of their active educational work. The knowledge given by the teacher must be consciously understood and strengthened by the students. The acquired scientific information should be absorbed into the inner world and spirituality of students, develop their mind, memory and worldview. Students should become accustomed to awareness, accuracy, activity, initiative, business acumen, creative attitude to the work done, for which the teacher 
should use the most optimal methods. It is important to observe a number of requirements when working on the principle of consciousness and activity. These requirements can be systematized as follows:

1. The student must be able to prove what he says, to be able to present evidence.

2. The student must be able to express the material in his own words.

3. The student must be able to use the knowledge learned independently.

If the above requirements are met, it means that the student will be able to consciously and actively master the knowledge given to him (Sadikov, 2014, 176-177).

This means that in biology classes, students must be able to present evidence when working individually on topics related to plants, flowers, blossoms, birds, animals, and fish. For this, biology teachers are obliged to create all conditions for them. Or, in individual activities, students should be able to make comparisons when expressing biological terms in their own words. Professor N. M. Kazimov shows that comparison is an inextinguishable torch of the mind. In this case, they will consciously assimilate the knowledge given to students in biology classes, and then they will become more active.

One of the most important principles that a teacher will refer to in biology lessons is the principle of visibility.
This principle allows students to get acquainted visually with didactic materials on topics in biology classes.

In the pedagogical process, not only in the teaching process, but also in the transfer of knowledge, skills and habits, that is, in teaching, it is not enough to comment on statements on any topic. During the training, creatures related to the topic, such as pictures, scoreboard, diagrams, tables, portraits, items, elements, facts, objects, things, including trees, plants, seeds, sprouts, insects, reptiles, planes, floats and other means, and Demonstration of other such teaching materials and examples is, in principle, one of the main features of the learning process. The creation of visibility in the lesson and thus the reference to this process as a principle has a very ancient history. The founder of scientific pedagogy, the prominent Slavic (Czech pedagogue in some sources) Jan Amos Comenius, called visibility the golden rule, and the book "The Great Didactics" revealed the scientific nature of visibility as a principle (Sadikov, 2018: 105).

Conclusions. Indeed, the principle of visibility, which must be applied in biology classes, can be considered a golden rule. Because in biology lessons, when didactic examples that are considered necessary to be presented on the basis of program materials are visually demonstrated, first of all, students try to make scientific comparisons.

1. Sadıqov F. B. Pedaqogika. Baku : Adiloğlu. 2010.

2. Orucov F. M. Biologiyanın tedrisinde yeni texnologiyaların tetbiqi istiqametleri. Baku : Mütercim. 2007.

3. Kazımov N. M. Ali məktəb pedaqogikası. Baku : Elferül. 2006.

4. Kazımlı K. Biologiyanın tədrisində fəal təlim metodlarının tətbiqi xüsusiyyətləri. Research Papers of the Institute of Education of the Azerbaijan Republic, Cild: 84, № 4. 2017.

5. Azərbaycan Respublikasının ekologiya qanunvericiliyi (normativ-hüquqi aktlar toplusu). II cild. Baku : Qanun. 2006.

6. Sadıqov F. B. Pedaqogika. Baku: Adiloğlu. 2011.

7. Tahirli, S. Tebiet. Bildiklerimiz ve Bilmediklerimiz. Ayna Uşaq Ensiklopediyası. Baku : Ayna Metbu Evi, 2004.

8. Eliyev, N. Təlimin Qanunauyğunluqları və Prinsipləri. 13/05/2020. URL: http://mdrk.edu.az/muhazireler/ 52-pedaqogikadan-muhazireler.html.

9. Sadıqov F. B. Pedaqogika. Baku : Adiloğlu. 2012.

10. Sadıqov F. B. Pedaqogika. Baku : Adiloğlu. 2014.

11. Sadıqov F. B. Ümumi pedaqogika. Baku : Genclik. 2018.

\section{REFERENCES}

1. Sadigov F. B. (2010). Pedagogy. Baku: Adiloglu [in Azerbaijani].

2. Orujov F. M. (2007). Directions of Application of New Technologies in Teaching Biology. Baku: Translator [in Azerbaijani].

3. Kazımov N. M. (2006). Higher Education Pedagogy. Baku: Alfarul [in Azerbaijani].

4. Kazıml K. (2017). Features of Application of Active Learning Methods in Teaching Biology. Research Papers of the Institute of Education of the Azerbaijan Republic, Vol. 84, No. 4 [in Azerbaijani].

5. Ecological legislation of the Republic of Azerbaijan (collection of normative-legal acts, II volume). Baku: Law, II cild. Baku: Qanun 2006 [in Azerbaijani].

6. Sadigov F. B. (2011). Pedagogy. Baku: "Adiloglu” [in Azerbaijani].

7. Tahirli S. (2004). Nature. What we Know and What We Do Not Know. Mirror Children's Encyclopedia. Baku: Ayna Press House [in Azerbaijani].

8. Eliyev N. (13/05/2020). Regularities and Principles of Training. Retrieved from: http://mdrk.edu.az/muhazireler/52pedaqogikadan-muhazireler.html [in Azerbaijani].

9. Sadigov F. B. (2012). Pedagogy. Baku: "Adiloglu” [in Azerbaijani].

10. Sadigov F. B. (2014). Pedagogy. Baku: "Adiloglu” [in Azerbaijani].

11. Sadigov F. B. (2018). General pedagogy. Baku: Youth [in Azerbaijani]. 